УДК 631.81

(C) І.М. Мерленко, к. с.-Г. н.

Луцький національний технічний університет

\title{
АГРОЕКОЛОГІЧНІ АСПЕКТИ ВИКОРИСТАННЯ НЕТРАДИЦІЙНИХ ДОБРИВ „БІОТЕРМ-С” В УМОВАХ ЗАХІДНОГО ПОЛІССЯ УКРАЇНИ
}

Через дефіцит традииійних органічних та незбалансоване застосування мінеральних добрив знижується родючість грунтів та якість сільськогосподарської продукиї. У Волинській області розпочато виробнищтво нетрадииійних добрив - продуктів ферментачії „Біотерм-С”. Такі добрива підвищують урожайність сільськогосподарських культур, знижують антропогенне навантаження на грунти, їх можна використовувати в системі органічного землеробства. 


\section{„БІОТЕРМ-С”, ОРГАНІЧНЕ ЗЕМЛЕРОБСТВО, УРОЖАЙНІСТЬ}

Постановка проблеми. Інтенсивне та не завжди науково обгрунтоване використання грунтів, внесення пестицидів та агрохімікатів, дефіцит органічних добрив зумовили низку екологічних проблем, які пов'язані 3 деградацією грунтового покриву, забрудненням довкілля та зниженням рівня урожайності та якості вирощеної продукції.

Крім дефіциту мінеральних добрив, спостерігається їх незбалансоване внесення. Так, ще у досить "благополучному" 1990 році на Волині було внесено 252 кг/га діючої речовини NPK у такому співвідношенні - 1,5:1:1,3, а в 2015 році співвідношення між макроелементами становило вже 5,2:1:1,3 при загальному їх внесенні менше 40 кг/га діючої речовини NPK.

Аналіз останніх досліджень і публікацій. Недостатне виробництво гною через різке скорочення поголів'я ВРХ та свиней не дає можливості вирішити проблему відтворення родючості грунту. Статистичні дані вказують на те, що якщо в 1990 році кількість голів ВРХ в Україні становила 24,6 млн., 2003 року всього 6,5 млн.[4], то у січні-лютому 2019 року загальне поголів'я ВРX скоротилось до 3,5 млн. - це найменший показник за усю задокументовану історію [10].

У 1990 р. на Волині вносили по 15 т/га органічних добрив, то сьогодні - менше 3 [3].

Через це щорічні втрати гумусу у Волинській області становлять до $0,1-0,15 \%$, більше половини зразків сільськогосподарської продукції є забрудненими важкими металами та залишковими кількостями пестицидів, 3 них близько $2 \%$ - 3 перевищеннями ГДК. Ця проблема загострюється у зв'язку із вступом України до Світової організації торгівлі. Неякісна продукція буде швидко витіснена з міжнародного ринку.

Частково вирішити проблему дефіциту органічних добрив в умовах Західного Полісся може виробництво і застосування нетрадиційних органічних добрив „Біотерм-С” [8].

У свій час розробки, пов'язані 3 ферментованими добривами були запатентовані [5,6].

Мета дослідження. Мета досліджень полягає у вивченні ефективності нових нетрадиційних органічних добрив „Біотерм-С”, виготовлених методом біоферментації, в контексті біологізації землеробства в умовах Західного Полісся України.

Дослідження ефективності нових добрив проводили на території Волинської та Рівненської областей методом польових та 
лабораторних експериментів, біометричних спостережень, статистичних обрахунків. Аналізи якості рослин та агрохімічних показників грунту проводили в сертифікованих лабораторіях Волинського центру „Облдержродючість”.

Результати дослідження. Перспективним напрямком для стабілізації біопродуктивності грунтів можуть бути нові види добрив, виготовлених із місцевої сировини (гній, курячий послід, торф, сапропель, фосфорити) шляхом ферментації. Вона використовується для зменшення втрат поживних елементів в одних видах (гній, послід) та зростання доступності для рослин в інших інертних ресурсах (торф, сапропель, фосфорити, тирса). Головна різниця полягає у тому, що термін ферментації протікає у 10-12 разів швидше за звичайне компостування. Крім цього, в процесі біоферментації гинуть яйця та личинки гельмінтів та мух, відбувається знезараження компосту від патогенних мікроорганізмів, втрачає схожість насіння бур'янів [8].

У розвинутих країнах світу розвиваються альтернативні методи ведення сільськогосподарського виробництва: органічне, біодинамічне, екологічне...[9].

Органічне землеробство дає можливість застосовувати гній, компости, кісткове борошно, “сирі” породи: доломіт, глауконітовий пісок, польовий шпат, базальтовий пил, крейду, вапно. При цьому повністю забороняється або частково обмежується застосування синтетичних мінеральних добрив та агрохімікатів.

Для позитивного вирішення впровадження органічної системи землеробства спочатку необхідно провести детальний агроекологічний моніторинг грунтів. Дослідження показують, що близько $60 \%$ площ земель Волинської області придатні для переходу на органічне землеробство.

За один рік практично неможливо перейти на органічну систему землеробства, тому існує перехідний період, який може тривати 2-5 років. За цей час необхідно повністю відмовитись від мінеральних добрив, а розширяти внесення нетрадиційних органічних добрив, посівів сидератів та багаторічних трав, залучення соломи та інших рослинних решток.

Однак, за твердженнями деяких авторів, повна відмова від мінеральних добрив в галузі зерновиробництва може значно знизити рівень врожайності та зменшити обсяги виробництва зерна. Доповнення нетрадиційних органічних добрив певною кількістю мінеральних необхідне для компенсації потреб рослин в елементах живлення, зокрема в азоті, на певних етапах розвитку. Таке поєднання дозволяє отримувати екологічно чисту продукцію 
без зниження обсягів іiі виробництва [2,7]. Але така система землеробства не буде сертифікована згідно вимог IFOAM.

Для переходу господарств на альтернативні системи землеробства повністю підходить новий продукт, який виготовляється 32006 року на Волині. В результаті проведеної наробки, отримали нове добриво "Біотерм-С", яке характеризується такими показниками: $\mathrm{N}-2,76 \% ; \mathrm{P}_{2} \mathrm{O}_{5}-3,23 \% ; \mathrm{K}_{2} \mathrm{O}-1,12 \%$.

Проведені польові дослідження на дерново-слабопідзолистих грунтах Західного Полісся України показали, що застосування добрив, створених на основі місцевих сировинних ресурсів (торф, курячий послід, зернисті фосфорити) шляхом ферментації, відрізняється комплексним впливом на грунтові процеси та біопродуктивність сільськогосподарських культур.

Максимальну врожайність бульб картоплі забезпечує внесення "Біотерму-С" в нормі 10 т/га на мінеральному фоні - 290 ц/га, що забезпечує і найвищий вихід крохмалю з одиниці площі (44 ц/га) (табл. 1).

Таблиця 1 - Вплив “Біотерм-С” на продуктивність бульб картоплі, ц/га [1]

\begin{tabular}{|c|c|c|c|c|c|}
\hline $\begin{array}{l}\text { № } \\
\text { п/п }\end{array}$ & Варіанти досліду & Врожай & $\begin{array}{c}+- \text { до } \\
\text { контролю }\end{array}$ & $\begin{array}{c}\text { Вихід } \\
\text { крохмалю }\end{array}$ & $\begin{array}{c}\text { +- до } \\
\text { контр } \\
\text { олю }\end{array}$ \\
\hline 1. & Контроль (без добрив) & 116 & - & 15 & - \\
\hline 2. & Гній 30 т/га+ $\mathrm{N}_{90} \mathrm{P}_{60} \mathrm{~K}_{120}$ & 268 & 152 & 43 & 28 \\
\hline 3. & $\mathrm{~N}_{90} \mathrm{~K}_{120}+\mathrm{P}_{60}$ 3. ф. (Милятин) - фон I & 222 & 106 & 32 & 17 \\
\hline 4. & Фон I + “Біотерм-C" - 5 т/га & 242 & 126 & 37 & 22 \\
\hline 5. & Фон I + “Біотерм-C" - 10 т/га & 290 & 174 & 44 & 29 \\
\hline 6. & “Біотерм-C" 5 т/га + $\mathrm{N}_{90} \mathrm{~K}_{120}-$ фон II & 241 & 125 & 37 & 22 \\
\hline 7. & Фон II + $\mathrm{P}_{60}$ фосфоритне борошно & 254 & 138 & 36 & 21 \\
\hline 8. & Фон II + $\mathrm{P}_{60}$ 3. ф. (Милятин) & 246 & 130 & 36 & 21 \\
\hline 9. & “Біотерм-C" - 10 т/га & 180 & 64 & 25 & 10 \\
\hline 10. & NPK - вир. по варіанту № 9 & 201 & 85 & 27 & 12 \\
\hline \multicolumn{3}{|c|}{$\mathrm{P}, \%$} & \multicolumn{3}{|c|}{2,6} \\
\hline
\end{tabular}

Примітка: з. ф. - зернисті фосфорити.

Застосування "Біотерму-С" позитивно вплинуло на фосфатний і калійний режими дерново-слабопідзолистого грунту. При цьому вміст рухомих форм фосфору та обмінного калію зростає на 5-31 мг/кг грунту в порівнянні із традиційною системою удобрення. 
Внесення добрив „Біотерм-С” дозволяе отримати високоякісні врожаї коренеплодів моркви в умовах Західного Полісся України. Найбільш ефективними виявились добрива, до складу яких входить курячий послід та торф, в дозах 10 т/га, які забезпечують приріст урожаю 27-99\% до контролю.

Внесення 5 і 10 т/га добрив „Біотерм-C” забезпечило зростання на 20-35 \% урожайності зернових культур в порівнянні 3 не удобреним контролем.

Отримані результати можна пояснити збалансованим вмістом NPK у доступних для рослин формах в добривах, а також в значній кількості органічної речовини та мікроелементів.

Висновки. Наявність місцевої сировинної бази (курячий послід, торф, зернисті фосфорити, тирса) та напрацьованих технологій дозволяє в умовах Західного Полісся України вперше виробляти високоякісні добрива під назвою “Біотерм-С". При дотриманні вимог IFOAM щодо підбору площ та технологій виробництва з використанням добрив "Біотерм-С" на Волині $\epsilon$ всі можливості щодо переходу на органічну систему землеробства. Застосування "Біотерму-С" сприяе істотному зростанню врожайності та якості вирощеної продукції. Поєднання даного добрива $з$ мінеральними добривами дозволяє отримувати значно більші врожаї.

В перспективі слід розширити перелік досліджуваних культур та норми застосування “Біотерму-С" в чистому вигляді або, залежно від поставленої мети, сумісно 3 мінеральними добривами.

\section{Література}

1. Гаврилюк В.А., Мерленко I.М., Псалтира С.С. "Біотерм - С" - нове слово в органічному землеробстві // Інформаційно-методичний вісник. -2006. -№2. - Луцьк. - С.60-62.

2. Глущенко Л.Д., Троценко 3.Г., Сокирко П.Г. та ін. Вплив органомінеральної системи удобрення на поліпшення родючості грунту, продуктивності сільськогосподарських культур та агроекологічної обстановки в регіоні//Агроекологічний журнал. - 2007. - № 1. C.34-36.

3. Звіт Волинського обласного державного проектнотехнологічного центру охорони родючості грунтів i якості продукції про проведення проектно-технологічних робіт у 2005 році.-Луцьк-2006. -75 с.

4. Клюй В.С., Рибак Л.Х., Клюй А.С. Україна і світ: Інформаційний бюлетень. - К.:НАУ, 2008. - 27с. 
5. Пат. на корисну модель 75068 Україна, МПК (2012.01) А01С 21/00. Спосіб удобрення картоплі за внесення ферментованого добрива на дерново-підзолистих грунтах / Засєкін Н. П., Лопушняк B.I., Мерленко I.M., Гаврилюк В.А., Зінчук М.I. ; заявники і патентовласники Засєкін Н.П., Лопушняк В.I., Мерленко I.M., Гаврилюк В.А., Зінчук М.I. - № u201203601; заявл. 26.03.2012; опубл. 26.11.2012, Бюл. № 7.

6. Патент на корисну модель №49595 "Виготовлення продукту біоферментації з додаванням зернистих або жовнових фосфоритів/ Мерленко І.М. Зареєстровано 11.05. 2010. Бюл. №9. Номер заявки и 2008 07077. МПК (2000) C05F 17/00.

7. Петрунів В.В. Вплив нетрадиційних органічних добрив на продуктивність озимої пшениці в умовах Західного регіону України: Автореф. дис. канд. с.-г. наук: 06.01.04/ НАУ - К.,2000. $20 \mathrm{c}$.

8. Шевчук М.Й., Мерленко І.М. Технологія приготування добрив „Біотерм-С” методом біоферментації в умовах Західного Полісся України// Наукові праці: Науково-методичний журнал. Т.82. - Вип. 69.- Миколаїв: Вид-во МДГУ ім. П.Могили, 2008. C.38-40.

9. Якість грунтів та сучасні стратегії удобрення / За ред. Дж. Хофмана, Д. Мельничука, М. Городнього. - К.: Арістей, 2004. $488 \mathrm{c}$.

10. https://agravery.com/.../kilkist-goliv-vrh-z-pocatku-roku-sko. [Інтернет-ресурс]. 